\title{
GATA1 Exon 2 Mutation
}

National Cancer Institute

\section{Source}

National Cancer Institute. GATA1 Exon 2 Mutation. NCI Thesaurus. Code C132233.

A molecular genetic abnormality indicating the presence of a mutation in exon 2 of the GATA1 gene. 